\title{
FEATURES OF THE USE OF ICT IN SPEECH THERAPY PRACTICE OF PRESCHOOL INSTITUTIONS
}

\author{
Anna Khilya \\ Vinnytsia Mykhailo Kotsiubynskyi State Pedagogical University, Ukraine \\ Alona Valeriiva Korol \\ Vinnytsia Mykhailo Kotsiubynskyi State Pedagogical University, Ukraine
}

\begin{abstract}
Today, an important part of work in a preschool institution is working with children with disabilities in the development of speech. Since the formation of speech skills in children at this age has a number of features and requires attention for further socialization and selfrealization of the child.

That is why in the article we analyze the state of modern psychological and pedagogical research on the feasibility and prospects of using information and communication technologies in the practice of speech therapist, in particular, in preschool educational institutions. As part of a study conducted based on the work of speech therapists in a preschool institution and a private educational organization - a speech club, we established that information and communication technologies are able to provide computerisation and high efficiency of the process of the development and speech correction of children with speech impairments. Obstacles to the introduction of such technologies into the practice of speech therapy are identified and ways to overcome obstacles and difficulties in solving the problems of computerisation of the speech therapy process are presented.

We have proved the increase of effectiveness of the speech therapy process as a result of remote interaction of a speech therapist with teachers, parents and the public using ICT.
\end{abstract}

Keywords: information and communication technologies, preschool education, speech therapy.

\section{Introduction}

In the modern world, it is difficult to imagine a sphere where information and communication technologies are not used. Digitalization and computerisation have become an integral part of all processes of human life, in all areas of development. In addition, these modern concepts have influenced one of the most «stable» systems - education.

Teachers should not only master the technical means of learning and start using technology to organize the learning process. They need to integrate technology into all teaching processes. In each lessons they should be used a 
demonstration of materials on the technical means. Some exercises children can perform by using gadgets. Some parts of the work in the classroom they can carry over and do online.

However, in our research we did not focus on educational issues, but turned to the issues of the gradual introduction of ICT into the corrective processes of accompanying logopedic support of children with disabilities, in particular children with speech disorders.

In addition, since we have to provide logopedic services as early as possible, our main issues are addressed in the case of speech therapists in preschool education. The priority areas for improving the quality of speech therapy services in the practice of preschool educational institutions are:

- Awareness of perception, principally the acquisition of new skills teaching speech therapy that meets today.

- Readiness to use information and communication technologies as an auxiliary developing therapeutic, learning and educational resource.

Based on current trends, we identified the following problems for research:

- Identify obstacles to the implementation of ICT in the practice of speech therapy.

- Identify the main ways to overcome obstacles and difficulties in solving the problems of computerization of speech therapy process.

- $\quad$ Present the results of increasing the efficiency of using ICT in speech therapy practice of preschool institutions.

The object of our research - speech therapy practice of preschool institutions.

The aim of the research is to analyze the increase in the effectiveness of the speech therapy, and a result of the remote interaction of a speech therapist with teachers, parents and the public using information and communication technologies.

The main research methods: study and analysis of current research, exchange of experience on the use of ICT in speech therapy practice work in preschools; interviews and research in practice of the experience of using remote cooperation of a speech therapist with teachers, parents and the public to increase the effectiveness of these processes.

\section{Methodology of Research General Background of Research}

Today, an important part of work in a preschool institution is working with children with disabilities in the development of speech. Since the formation of 
speech skills in children at this age has a number of features and requires attention for further socialization and self-realization of the child.

That is why in the article we analyze the state of modern psychological and pedagogical research on the feasibility and prospects of using ICT in the practice of speech therapist, in particular, in preschool educational institutions.

In our research, conducted with speech therapists in preschools and private organization LogoClub ${ }^{\mathrm{TM}}$, we established that information and communication technologies are able to provide information and high efficiency of correctional development of children with speech disorders. Identified barriers to introduction of technology in the practice of speech therapy activities and our thinking about ways to overcome obstacles and difficulties in solving the problems of informatization process of correction.

\section{The Theoretical Background}

Problems of computerisation of education require comprehensive fundamental research on the processes of creating and using ICT tools. This is due to the rapid development of technology, the emergence of not only new electronic tools and resources, but also new technology platforms, tools that change the understanding of the infrastructure of the organization of the learning process and its information content (Shyshkina, 2012).

Firstly, under the computerisation of education in modern society, it is customary to consider a set of interrelated organizational and legal, socioeconomic, educational, methodological, scientific, technical, production and management processes. These processes are aimed at satisfying the information, computing, telecommunication needs (and other needs associated with the implementation of ICT) of the participants in the educational process. And also for those who manage and provide these processes, including their scientific and methodological support and development (Bykov, 2010). Thus, we can indicate that the issue of computerisation of the correction process, namely, speech therapy activities, is also an integral part of the modernization of education in preschool institutions.

Secondly, as practice shows, many speech therapists, despite the possibilities and advantages of using ICTs, continue to rely on traditional methods of speech development in children, including in matters of interaction with parents, other specialists, and the public. Most often, conducting individual conversations, speaking at parent meetings, collecting and sharing data through notebooks of joint observations (Korol, 2016). This significantly reduces the role of the family and others in the formation of the «correct» speech in the child and creates barriers to quality communication. 
Thirdly, it is a matter of professional competence of a speech therapist. In part, the issues of organizing speech therapy work can be attributed to the issues of inclusive education - working with children with special educational needs. So, according to Kolosova, Khilya, Sarancha (2019), communicating with children with disabilities on the principles of humanism, tolerance and partnership forms specialists' own approaches to cooperation, reflection and empathy. It also affects the development of personal qualities and professional skills, enriching the cognitive-informational and value-personal sphere of speech therapist.

At the same time, for our research, an important element of high-quality work on the formation of the correct speech of the child is work with parents and carriers. Since these are the «first» teachers and role models, which form the image of the child's self-realization in life.

The work of a speech therapist in this direction makes it possible:

- $\quad$ systematize, think through a focused set of work for a speech therapist and all related interactions;

- $\quad$ create quality support for the teaching staff in the correction processes for the diagnosis, correction and prevention of speech disorders in preschool children;

- $\quad$ create the necessary conditions for interaction with parents to improve the results of corrective developmental activities and increase the «level of tolerance» of society (Korol, 2018).

- For the pre-school educational institution, an important stage in computerisation is the successful creation of a unified information environment in accordance with the following conditions (Tsymbaliuk, 2012):

- $\quad$ providing computers of all blocks of the information space;

- development of motivation for the use of information systems by each of the performers in their area of work;

- $\quad$ providing advanced training in the field of information technology for all employees;

- distribution of the total volume of implementing information;

- $\quad$ organization of a local network in the institution;

- multimedia office equipment;

- $\quad$ providing free access to the Internet;

- organization of the exchange of experience in the preschool institution.

However, at the same time, we need to note that it is rather difficult to fulfill the above conditions immediately and in full. Thus, the speech therapist's willingness to attract and implement ICT in his practice becomes an important element, especially with regard to the introduction of promising technologies 
such as cloud computing, adaptive information and communication networks, virtual and mobile training, etc. (Shyshkina, 2012). So, to work directly with the parents of a child with speech disorders, you can use:

- the Internet, which allows «active» parents to independently find the necessary information in various information sources (on websites, blogs, etc.), as well as establish personal contacts;

- email - provides the opportunity to correspond with a speech therapist, ask questions and receive answers to them, discuss current problems and organizational issues;

- $\quad$ social networks - provide various ways of exchanging information, in particular correspondence (as well as chat), watching videos and images, listening to audio recordings, etc.;

- videoconferences (video bridge; video seminar; webinar; Skype connection) - allow you to "gather» at the appointed time in the virtual classroom and work in much the same way as during a regular seminar or training, perform tasks of a speech therapist and ask each other questions;

- online consultations - provide an opportunity to ask and receive answers to questions, discuss current problems in real time;

- thematic blog - provides access to a selection of information materials that are regularly updated by a specialist - the author of the blog;

- $\quad$ forum - provides an opportunity to discuss a specific issue by sending messages, read and respond to messages from participants;

- $\quad$ SMS messages - create opportunities for informing on a specific occasion (Bielienka, Derevianko, Kudykina, 2012; Khilya, 2018; Korol, 2016; Sadova, 2012).

All the proposed mechanisms of cooperation allow you to "start» the mechanisms of empathy. That is, include empathy among the participants, reflection, which provide family members with awareness of their own preferences and personality characteristics (Lazarenko, Khilya, Kolomiiets, 2017).

\section{Sample of Research}

We have proved the effectiveness of the process of corrective development as a result of remote interaction of a speech therapist with teachers, parents and the public using information and communication technologies. 
Khilya \& Korol, 2021. Features of The Use of Ict in Speech Therapy Practice of Preschool Institutions

Problems of the research:

1. To identify barriers to the implementation of ICT in speech therapy practice.

2. To outline the main ways to overcome obstacles and difficulties in solving the problems of computerisation of the correctional development process.

3. Present the results of improving the effectiveness of the correctional development process using ICT.

\section{Results of the Research}

The results of the pedagogical experiment presented in this paper are part of a research that was conducted in 2017-2018. That also was the basis for further development and is being implemented in the Vinnytsia region (15 districts and the city of Vinnytsia) of the next stage of the research, which continues to this day.

We selected 20 speech therapists from preschool educational institutions of the city of Vinnitsa and Vinnitsa region. The experience of each of them was at least 5 years. All of them underwent interviews as part of joint training and advanced training. Thanks to this, we were able to determine that individual consultations, individual meetings with parents of children and parent-teacher meetings occupy more than $80 \%$ of the time allocated for a speech therapist. Which quite strongly influences the formation of the "policy» of ICT in the correctional development work with children with varying degrees of speech impairment. During the interview, it was revealed that in the process of interaction with the parents of a child with speech impairments, speech therapists use the capabilities of ICT at a fairly low level (Table 1).

The survey of participants showed that among the biggest problems in the organization of communication in the correctional development process using ICT are the following:

- Parents prejudice to the quality and effectiveness of such cooperation - 19 people;

- Lack of skills of ICT use in speech therapists, in some cases even basic - 16 people;

- $\quad$ Lack of quality Internet or gadgets that could provide such interaction (both speech therapists and parents of children) - 4 people.

We have chosen only the main «excuses» for the introduction of ICT in the practice of working with children with speech disorders. It is possible to note separately among answers: "Parents do not trust gadgets to children», "The Internet is only a toy», "It is better to work in an office where you see the child and what she does», but all of them are somehow connected with the main ones. 
Table 1 The Results of an Interview with Speech Therapists on the Use of ICT in the Process of Organizing Interaction with Parents to Improve the Results of Corrective Developmental Classes

\begin{tabular}{|c|c|c|c|c|c|c|}
\hline \multirow[b]{3}{*}{ № } & \multirow[b]{3}{*}{$\begin{array}{c}\text { Type of interaction } \\
\text { using ICT }\end{array}$} & \multicolumn{4}{|c|}{$\begin{array}{c}\text { Percentage of respondents using } \\
\text { speech therapy practice }\end{array}$} & \multirow[b]{3}{*}{ Comment } \\
\hline & & \multicolumn{2}{|c|}{ Before training } & \multicolumn{2}{|c|}{ After training } & \\
\hline & & $\stackrel{\mathscr{D}}{\mathscr{D}}$ & $\begin{array}{l}\stackrel{\mathscr{D}}{\Xi} \\
\stackrel{0}{\Xi} \\
\stackrel{0}{\circ}\end{array}$ & $\stackrel{\mathscr{D}}{D}$ & $\begin{array}{l}\stackrel{\mathscr{a}}{\Xi} \\
\stackrel{0}{\Xi} \\
\stackrel{\Xi}{\circ}\end{array}$ & \\
\hline 1. & Internet & 4 & 16 & 18 & 2 & $\begin{array}{l}\text { Redirect to YouTube } \\
\text { channels, handout sites }\end{array}$ \\
\hline 2. & Email & 19 & 1 & 20 & - & $\begin{array}{l}\text { For organizing joint } \\
\text { events }\end{array}$ \\
\hline 3. & Social networks & 11 & 9 & 15 & 5 & $\begin{array}{l}\text { For organizing joint } \\
\text { events }\end{array}$ \\
\hline 4. & Video conferencing & - & 20 & 19 & 1 & - \\
\hline 5. & Online consultation & - & 20 & 18 & 2 & - \\
\hline 6. & Thematic Blog & 1 & 19 & 18 & 2 & - \\
\hline 7. & Forum & 3 & 17 & 20 & - & $\begin{array}{l}\text { Mostly professional in } \\
\text { Viber or local «talkers» }\end{array}$ \\
\hline 8. & SMS messages & 20 & - & 20 & - & - \\
\hline
\end{tabular}

To overcome these problems, we have proposed to use two next steps:

- $\quad$ Conducting an information campaign on social networks for parents and professionals, which included the organization of live broadcasts and working meetings with the coach on Instagram, and their distribution on the Internet;

- $\quad$ Training of specialists on the peculiarities of the use of ICT in their work.

Based on the feedback on the results of the information campaign and training, we were able to note that speech therapists were able to improve the quality of the correction process and effectively use ICT in their daily practice.

We also presented a comparison of the use of appropriate ICT tools by speech therapists after training (Table 1). What is important, in our opinion, since during the courses the features of their use were disclosed in more detail, as well as a number of non-standard technical solutions with the participation of programmers and IT specialists. The results have partially changed for the better, however, the workload of the main responsibilities and the time frame at the moment negatively affected the results of the repeated interview, since the data have changed insignificantly. However, in accordance with the plan for 
conducting this training, after three months a follow-up interview is planned, the results of which will work for the long term.

Thus, in our opinion, in preschool educational institutions, educators and methodologists should use such forms of work with speech therapists that are aimed at improving their qualifications and skills with the involvement of specialists. And, also such forms of work during which teachers in practice will be able to test the options for using ICT. Among such events can be noted: weeks of pedagogical excellence; master classes; pedagogical workshops and mentoring; workshops; work in pairs; thematic workshops; sharing best practices (Bielienka et al., 2012).

\section{Conclusions}

1. As a result of the research, we identified and described a number of obstacles to the implementation of ICT in speech therapy practice, which mainly concern the readiness and understanding of the mechanisms for using individual technologies. We also examined the issues of appropriate training of specialists to overcome obstacles and difficulties in solving the problems of computerisation of the process of correctional development, and, also identified positive trends that directly affect the correctional-developing component of speech therapy classes.

2. We were also partially able to present the results of preliminary testing of advanced training of speech therapists to increase the effectiveness of the process of correctional development of the child with speech disorders using ICT.

3. Since the selection of speech therapists for interviewing was quite limited in the framework of the training (20 respondents), we believe that it is necessary to continue the analysis of the situation with the introduction of ICT in the work of specialists in this area, as well as the need for appropriate training courses for speech therapists practicing more than five years.

Thus, we came to the conclusion that the issues of studying and finalizing the features of the use of ICT in the speech therapy practice of preschool institutions need to continue to be studied and developed in accordance with modern trends.

\section{References}

Bielienka, H., Derevianko, L., Kudykina, N. (2012). Vykorystannia wikitekhnolohii u suchasnomu doshkilnomu navchalnomu zakladi. VISNYK PSYKhOLOHII I 
PEDAHOHIKY, Zbirnyk nauk. prats / Pedahohichnyi instytut Kyivskoho universytetu imeni Borysa Hrinchenka, Instytut psykholohii i sotsialnoi pedahohiky. Vypusk 8, Kiev. Retrieved from http://www.psyh.kiev.ua/Збірник_наук._праць._-_Випуск_8.

Bykov, V. (2010). Suchasni zavdannia informatyzatsii osvity. Informatsiini tekhnolohii $i$ zasoby navchannia, 1(15). Retrieved from https://doi.org/10.33407/itlt.v15i1.

Khilya, A. (2018). Nestandartni formy roboty yak zasib pidvyshchennia yakosti osvitnikh posluh ta efektyvnosti inkliuzyvnoi shkoly. Inkliuzyvna osvita yak indyvidualna traiektoriia osobystisnoho zrostannia dytyny z osoblyvymy osvitnimy potrebamy : zbirnyk materialiv II Vseukrainskoi naukovo-praktychnoi konferentsii z mizhnarodnoiu uchastiu / redkol.: O. P. Demchenko, N. O. Komarivska, L. V. Liubchak, L. A. Prysiazhniuk. Vinnytsia: Merkiuri-Podillia, Vyp. 1, 154-158.

Kolosova, O., Hilya, A., Sarancha, I. (2019). Preparing of preschool teachers to working with children with special educational needs. Society. Integration. Education. Proceedings of the International Scientific Conference. III, 83-93. Retrieved from http://dx.doi.org/10.17770/sie2019vol3.3998.

Korol, A. (2016). Tekhnolohiia «Fidbek» yak zasib spivpratsi vchytelia-lohopeda z batkamy. Vykhovatel-metodyst doshkilnoho zakladu, №11, 51-58. Kyiv: MTsFER, Ukraina. Retrieved from http://93.183.203.244:80/xmlui/handle/123456789/3891.

Korol, A. (2017). Dystantsiino-interaktyvni formy roboty yak vyd prosvitnytskoi diialnosti vchytelia-lohopeda. Visnyk Kamianets-Podilskoho natsionalnoho universytetu imeni Ivana Ohiienka. Korektsiina pedahohika i psykholohiia, Vypusk 8(2), 77-81. KamianetsPodilskyi: PP Medobory-2006. Retrieved from http://93.183.203.244:80/xmlui/handle/ $123456789 / 3865$.

Lazarenko, N., Khilya, A., Kolomiiets, A., (2017). Formuvannia v ditei z funktsionalnymy obmezhenniamy indyvidualnoi systemy znan sensozhyttievoho kharakteru zasobamy art-terapii. Osvita osib z osoblyvymy potrebamy: shliakhy rozbudovy, Vyp.13,130-142.

Sadova, N. (2012). Vedemo personalnyi bloh. Vykhovatel-metodyst doshkilnoho zakladu, 2, 53-55.

Shyshkina, M. P., Spirin, O. M., \& Zaporozhchenko, Y. G. (2012). Problems of informatization of education in Ukraine in the context of development of research of ictbased tools quality estimation. Information Technologies and Learning Tools, 27(1). Retrieved from https://doi.org/10.33407/itlt.v27i1.632

Tsymbaliuk, O. (2013). Vykorystannia IKT u doshkilnykh navchalnykh zakladakh. Pedahohichnyi poshuk, 3, 36-41. 